\title{
On the properties of filled plaster of Paris with metallurgical slag and plasticizing additive
}

\author{
Jumagul Turgunbaeva* \\ Tashkent State Transport University, Tashkent, Uzbekistan
}

\begin{abstract}
The article studies the properties of filled plaster of pair with metallurgical slag and a plasticizing additive. In particular, the optimal compositions of the composite Bukhara and Samarkand gypsum binders modified with the addition of GLENIUM 27S and metallurgical slag, the area of optimal compositions of the gypsum binder have been determined, and the physical and technical properties of the modified gypsum composition have been studied.
\end{abstract}

\section{Introduction}

The task of creating gypsum binders for various purposes, modified by a rationally selected complex of local mineral fillers using highly effective chemical additives, affordable and competitive in quality, is very urgent $[10,11,12,13]$.

This article aims to study the properties of a filled gypsum binder with the addition of a polycarboxylate superplasticizer. As the subject of research were selected: gypsum binder from the Samarkand and Bukhara gypsum plant, mineral filler metallurgical slag of the Bekabad metallurgical plant with the addition of the polycarboxylate superplasticizer GLENIUM 27S [4, 2, 6, 18, 20, 21].

The studies were carried out using modern physical and mechanical research methods, the analysis of the physical and technical properties of stucco from the Bukhara and Samarkand plants with optimal properties, metallurgical slag with a plasticizing additive and without an additive was carried out $[3,16]$.

\section{Materials and Methods}

The optimal composition of the modified gypsum binder is given in Tables 1 and 2. In this case, for metallurgical slag - 20\%, for superplasticizer GLENIUM 27S was - $1 \%$.

\footnotetext{
*Corresponding author: urinbekdj@mail.ru
} 
Table 1. Optimal formulations Bukharian composite gypsum binders modified with the additive GLENIUM 27S and metallurgical slag

\begin{tabular}{|c|c|c|c|c|c|c|}
\hline \multirow[b]{2}{*}{ № } & \multicolumn{3}{|c|}{ The composition, $\%$} & \multirow{2}{*}{$\begin{array}{c}\text { Grinding } \\
\text { fineness of } \\
\text { metallurgical } \\
\text { slag, \% } \\
\text { according to the } \\
\text { residue on sieve } \\
\text { № } 008\end{array}$} & \multicolumn{2}{|c|}{$\begin{array}{l}\text { The physico-technical } \\
\text { properties of the } \\
\text { composition }\end{array}$} \\
\hline & $\begin{array}{c}\text { Construct } \\
\text { ion } \\
\text { gypsum }\end{array}$ & $\begin{array}{l}\text { Metallu } \\
\text { rgical } \\
\text { slag }\end{array}$ & $\begin{array}{l}\text { Additive } \\
\text { GLENIUM } \\
\quad 27 \mathrm{~S}\end{array}$ & & $\begin{array}{c}\text { Compressive } \\
\text { strength, MPa } \\
\text { after } 28 \text { days } \\
\text { of theory / } \\
\text { exp. }\end{array}$ & $\begin{array}{c}\text { Softening } \\
\text { factor } \\
\text { theory/exp } \\
\text {. }\end{array}$ \\
\hline 1 & 85 & 15 & 0.5 & 14 & $16.1 / 16.2$ & $0.45 / 0.46$ \\
\hline 2 & 80 & 20 & 1.0 & 0 & $18.0 / 18.2$ & $0.48 / 0.47$ \\
\hline 3 & 75 & 25 & 1.2 & 5 & $16.1 / 16.2$ & $0.46 / 0.45$ \\
\hline
\end{tabular}

The analysis of the physical and technical properties of the building gypsum of the Bukhara plant with optimal properties, modified with metallurgical slag with a plasticizing additive and without additive, has been carried out. Comparison of the properties of these compositions showed that at the minimum cost in a given factor space for grinding the slag (the fineness of grinding the slag is $14 \%$ according to the residue on sieve №008), it is possible to add it to the composition of stucco in an amount of $-15 \%$ and superplasticizer GLENIUM 27S \%. Simultaneously, the strength of the gypsum stone remains at the level of the control composition (without additive), and the softening coefficient increases from 0.3 (gypsum without additive) to 0.45 . Slag in an amount of $20 \%$ and when ground to zero residue on a sieve № 008 with GLENIUM $27 \mathrm{~S}$ superplasticizer - $1.0 \%$ increases the strength of the gypsum stone by $10 \%$, the softening coefficient from 0.3 (gypsum without additives) to 0.48 . It was found that the maximum possible amount of slag is $25 \%$ (provided that it is ground 5\% based on the residue on sieve №008) with $1 \%$ superplasticizer, in the composition, in which there is no decrease in the strength of the gypsum stone less than the control values (for pure gypsum), with this increases the softening coefficient of gypsum stone from 0.3 (pure gypsum without additives) to 0.46 .

Table 2. Optimal formulations Samarkand composite gypsum binders modified with the addition of additive GLENIUM 27S and metallurgical slag

\begin{tabular}{|c|c|c|c|c|c|c|}
\hline \multirow[b]{2}{*}{ № } & \multicolumn{3}{|c|}{ The composition, $\%$} & \multirow[b]{2}{*}{$\begin{array}{c}\text { Grinding } \\
\text { fineness of } \\
\text { metallurgical } \\
\text { slag, \% } \\
\text { according to the } \\
\text { residue on sieve } \\
\text { № } 008\end{array}$} & \multicolumn{2}{|c|}{$\begin{array}{l}\text { The physico-technical } \\
\text { properties of the composition }\end{array}$} \\
\hline & 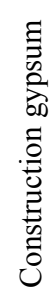 & 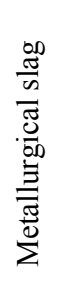 & 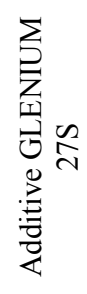 & & $\begin{array}{l}\text { Compressive } \\
\text { strength, MPa } \\
\text { after } 28 \text { days } \\
\text { of theory / } \\
\text { exp. }\end{array}$ & $\begin{array}{l}\text { Softening } \\
\text { factor theory } \\
\text { exp. }\end{array}$ \\
\hline 1 & 85 & 15 & 0.5 & 14 & $13.2 / 13.2$ & $0.36 / 0.37$ \\
\hline 2 & 80 & 20 & 1.0 & 0 & $14.3 / 14.5$ & $0.39 / 0.42$ \\
\hline 3 & 75 & 25 & 1.2 & 5 & $13.1 / 13.3$ & $0.37 / 0.37$ \\
\hline
\end{tabular}

A comparative analysis of the physical and technical properties of the gypsum compositions of the Samarkand plant with optimal properties, modified with metallurgical 
slag with a plasticizing additive, and a gypsum binder without additives showed that at the minimum cost in a given factor space for grinding the slag (the fineness of grinding of the slag is $14 \%$ according to the residue on sieve №008), it is possible to introduce it into the composition of stucco in an amount of $-15 \%$ and superplasticizer GLENIUM $27 \mathrm{~S}-0.5 \%$. Simultaneously, the strength of the gypsum stone remains at the level of the control composition (without additive), and the softening coefficient increases from 0.3 (gypsum without additive) to 0.36 . Slag in an amount of $20 \%$ and when ground to zero residue on a sieve №008 with GLENIUM 27S superplasticizer - 1.0\% increases the strength of the gypsum stone by $8 \%$, the softening coefficient from 0.3 (gypsum without additives) to 0.39 . It was found that the maximum possible amount of slag is $25 \%$ (provided that it is ground $5 \%$ based on the residue on sieve № 008) with $1 \%$ superplasticizer, in the composition, in which there is no decrease in the strength of the gypsum stone less than the control values (for pure gypsum), with this, the softening coefficient of gypsum stone increases from 0.3 (pure gypsum without additive) to 0.37 .

Having established the limits of the values of the ultimate strength in compression (not less than $6.4 \mathrm{MPa}$ - the strength of the control composition without additive) and the softening coefficient not less than 0.45 - for binders of medium water resistance $[1,5,7,8$, $9,14,17]$, the area of optimal compositions of gypsum binders, modified additives was obtained graphically and analytically GLENIUM 27S and metallurgical slag (Figure 1) $[15,19]$.

\section{Results and Discussion}

Photomicrographs were examined gypsum samples based on the modified gypsum binder optimal composition ( $20 \%$ of metallurgic slag fineness of $0 \%$ residue on sieve №008) and based on the binder, the composition of which is outside the established optimum range (15\% slag fineness $14 \%$ by the remainder of the sieve № 008) (Figure 1).

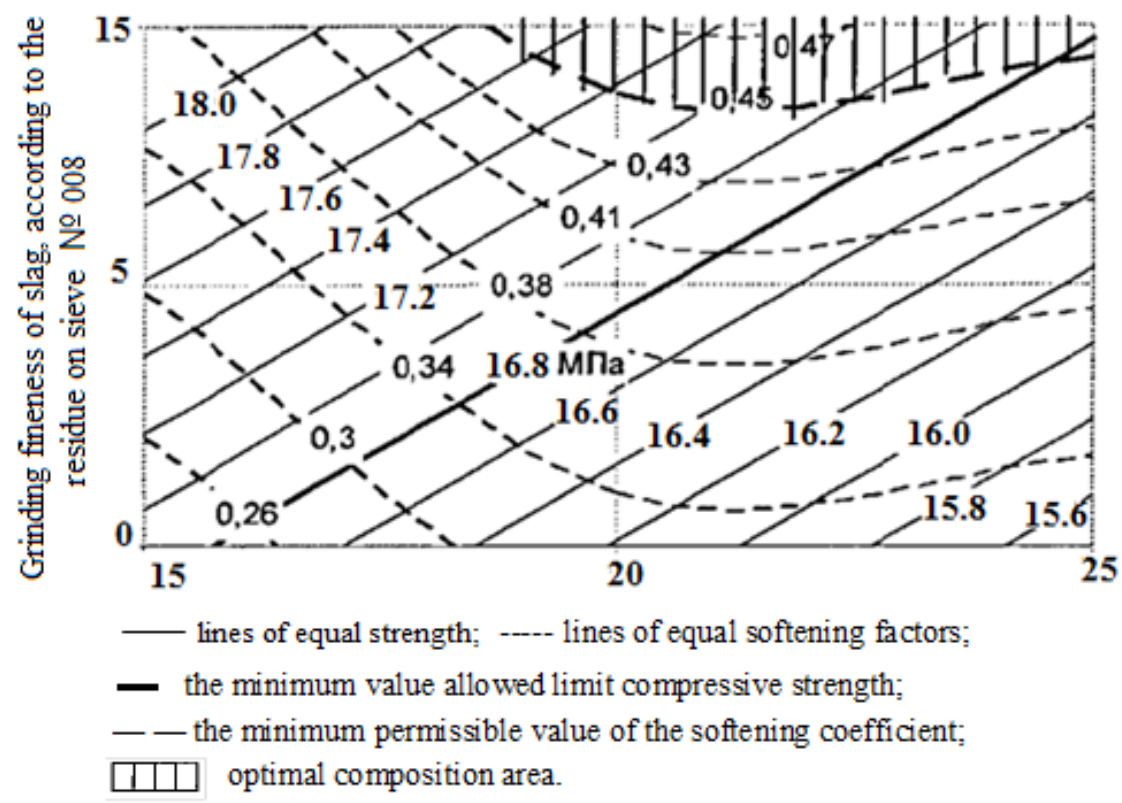

Fig. 1. The area of optimal compositions of gypsum binder, modified with GLENIUM 27S additive and metallurgical slag 
In figures 2 and 3 shown that two types of gypsum crystals are formed in the hardened stone: a mixture of stable and unstable. Unstable gypsum grains have a lamellar structure figure 2 .
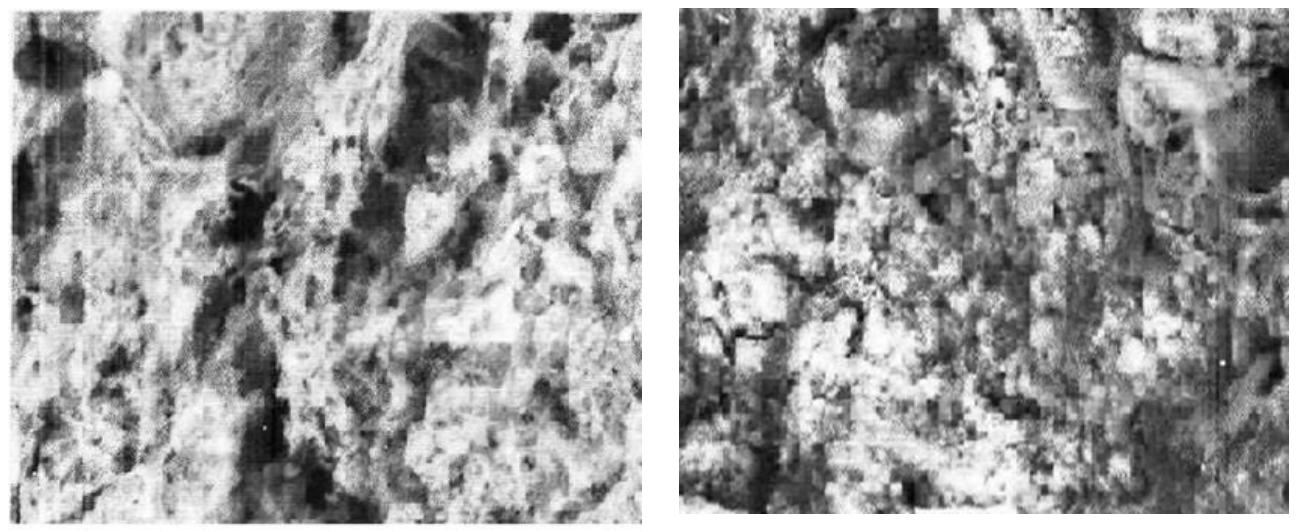

Fig. 2. Photomicrographs of gypsum-based binders are not included in optimal compositions. Corn plaster unstable with increasing X2000
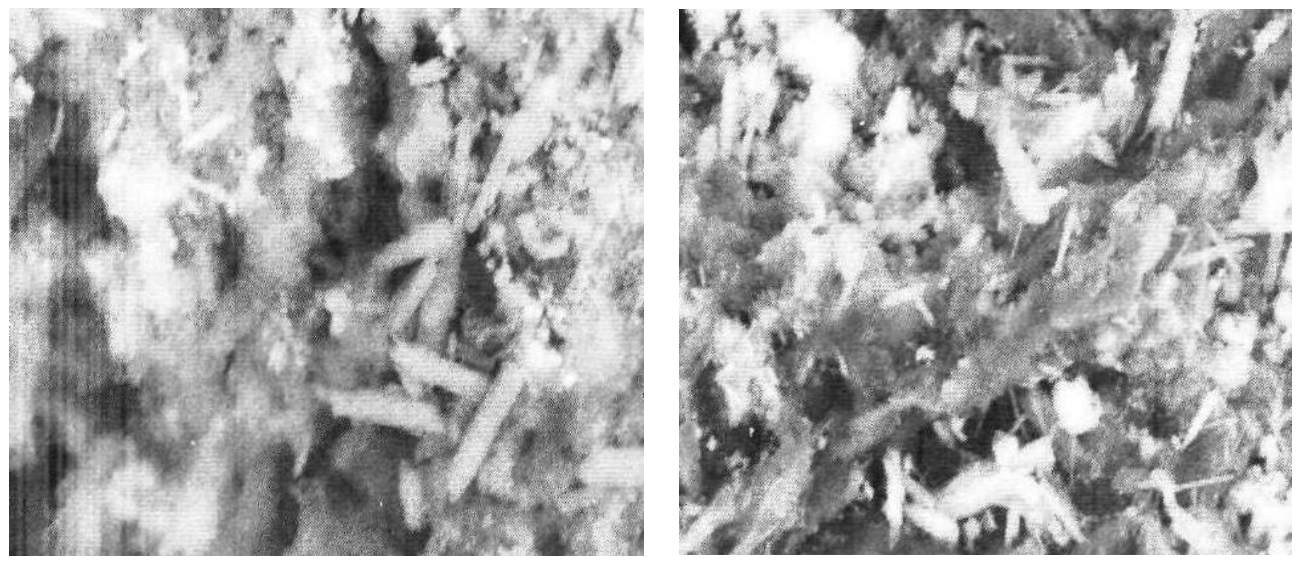

Fig. 3. Photomicrographs of gypsum-based binders are not included in optimal compositions (unstable gypsum in the recrystallization step in stable) with increasing X2000

The quantitative ratio of the two types of gypsum crystals is determined by the ratio of water: gypsum in the gypsum slurry. There are dominated by unstable gypsum crystals.

The images under an electron microscope (Figure 3.) also show the stages of recrystallization of metastable gypsum into stable gypsum. It is seen that the grains of metastable gypsum have strengthened, their morphology has been preserved.

Micrographs of a gypsum stone based on a modified binder of optimal composition are shown in (Figure 4.) In this case, gypsum crystallizes in very thin elongated crystals and their aggregates, which intertwine with each other, creating a felt structure. The growth of elongated gypsum crystals on the slag begins and occurs in different orientations. 

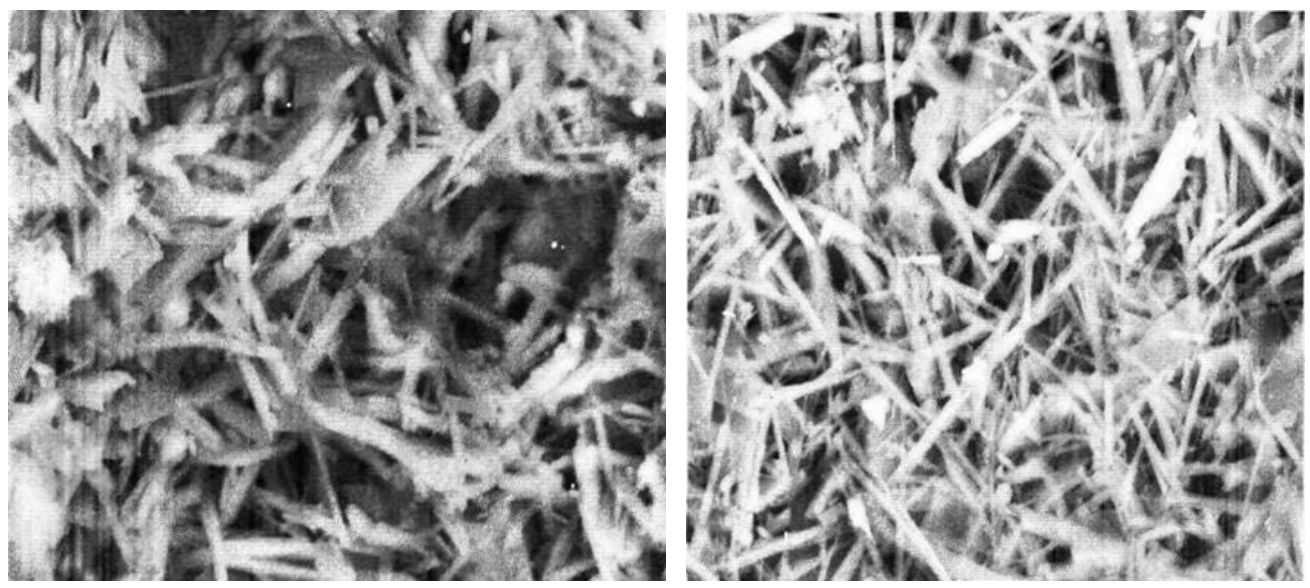

Fig. 4. Micrographs of a gypsum stone based on a binder of optimal composition (stable gypsum) at a magnification of $\mathrm{x} 2000$

\section{Conclusions}

1. The areas of optimal compositions of composite gypsum binders filled with metallurgical slag were obtained by graph-analytically;

2. Based on the need to obtain the required properties of the gypsum binder, the conditions for minimizing energy consumption for grinding the additive and the maximum degree of filling, the compositions of the compositions were optimized, and the strength and water resistance indicators of gypsum stone based on them were calculated; properties calculated graphically and analytically received experimental confirmation;

3. With the minimum costs for grinding in a given factor space and while maintaining the strength of the gypsum stone at the level of the control composition (without additives), it is possible to add metallurgical slag to the stucco composition (the fineness of grinding additive is $14 \%$ based on the residue on sieve №008) in the amount of $15 \%$.

4. It has been established that the maximum strength and water resistance of gypsum stone in a given factorial space are achieved when the additive is ground to zero residue on sieve №008; the amount of slag is $20 \%$, the superplasticizer GLENIUM $27 \mathrm{~S}$ is $1.0 \%$, and an increase in strength is observed by $10 \%$, and the softening coefficient is up to 0.39 and 0.48 .

5. By electron microscopy, it was found that with a different fineness of slag grinding, the degree of growth of new formations of gypsum crystals is different: the optimal fineness of grinding of the filler (to zero residue on sieve №008) promotes the formation of elongated crystals, which in turn provides an increase in the strength and water resistance of the gypsum stone.

\section{References}

1. Ivanitsky V.V., Ferronskaya A.B., Stambulko V.I. TU 21-02847757-1-90. Gypsum and anhydrite binders of increased water resistance, Technical conditions. Developed, State Association "Soyuzstroymaterialy" p. 11, (1990)

2. Vernigorova V.N., Makridin N.I., Sokolova Yu.A. Modern methods of studying the properties of building materials, p. 240, (2003)

3. Mineral raw materials in Uzbekistan, Industry overview, Federal Office for Foreign Trade Information, p. 16, Cologne, Berlin, (1996) 
4. Altykis M.G., Khaliullin M.I., Rakhimov R.Z. Influence of fillers on the properties of gypsum building materials, Construction Materials, № 9, pp. 20-21, (2005)

5. GOST 23789-2018 Plaster binders. Test methods (as amended).

6. Takhirov M.K., Turgunbaeva Zh.R. On the issue of substantiating the technology for obtaining dry building mixtures, TashIIT, Resource-saving technologies in construction, pp. 3-12, (2009)

7. Moreva I.V., Medyanik V.V., Sokolova Y.A. Composite gypsum binders in modern construction, p. 85, M.GASIS., (2004)

8. Gorbacheva M.I., Ignatov V.I., Ryabov G.G. Composite waterproof binder based on semi-aqueous gypsum. // Construction Materials. 1987. -№5. -26-27p.

9. Volzhensky A.V., Ivanov I.A., Vinogradov B.L. The use of ash and fuel slag in the production of building materials. $-\mathrm{M}$.: Stroyizdat, 1984-254p.

10. Volzhensky A.V. Mineral binders. -M .: Stroyizdat. 1986-472p.

11. Modified gypsum. Turgunbaeva Zh.R. TashIIT. Resource-saving technologies in construction. T-2010.-106-109p.

12. On the properties of plaster filled with metallurgical slag. Turgunbaeva Zh.R. "High technologies and innovations in science", State Research Institute "NATSRAZVITIE" St. Petersburg 2017.19-23p.

13. Moreva I.V., Medyanik V.V., Sokolova Y.A. Actual problems of theory and practice of composite gypsum binders Sat. scientific Proceedings of TsRO RAASN, 2, pp. 6467, Moscow (2003).

14. Volzhensky A.V., Ferronskaya A.V. Gypsum binders and products, p. 328, Moscow, (1974)

15. Turgunbaeva Zh.R. About optimization of compositions of composite gypsum binders with the addition of polycarboxylate superplasticizer and metallurgical slag. "Prospects for the application of innovative technologies in the field of architecture and construction" 4, pp. 144-146, Samarkand, (2016)

16. Vasilik P.G., Golubev I.V. Features of the use of Melflux polycarboxylate hyperplasticizers, Construction Materials, № 9, p. 242, (2003)

17. Li Guozhong, Li Jianguan, Guan Ruifang, Sui Su, Liu Huashi. Study of the water resistance of gypsum material. Cement-lime-gypsum int. № 8-9, pp. 87-93, (2003)

18. Saduakasov M.S. Theoretical foundations for increasing the strength of the structure of gypsum stone based on a plasticized binder, Construction Materials. -№ 3, pp. 1922, (1993)

19. Moreva I.V., Medyanik V.V., Sokolova Y.A., Valeev R.Sh. Optimization of the composition and properties of a composite gypsum binder modified with a carbonatecontaining additive, scientific, Proceedings of TsRO RAASN, issue Z, pp. 18-23, (2004)

20. Mokrushin A.N., Golubeev V.A., Obodovskaya L.A., Valtsifer V.A. Improving the physical and mechanical properties of gypsum by optimizing its fractional composition, Construction Materials, № 7. -p. 22, (1996)

21. Rakhimov R.Z. Problems of the rational use of local raw materials in the production of building materials, Construction, architecture and housing and communal services, № 1, p. 12-15, (1999) 